\title{
Animated Video of National Exam Subject Matter as An Online Learning Innovation for Elementary School Students in Sidokumpul Sub-District, Gresik
}

\author{
Zainal Abidin Achmad \\ Universitas Pembangunan Nasional "Veteran" Jawa Timur \\ e-mail: z.abidinachmad@upnjatim.ac.id \\ Muhammad Iqbal Dwi Fanani \\ Universitas Pembangunan Nasional "Veteran" Jawa Timur \\ Ghifari Zaka Wali \\ Universitas Pembangunan Nasional "Veteran" Jawa Timur \\ Rizkiyatul Nadhifah \\ Universitas Pembangunan Nasional "Veteran" Jawa Timur \\ Nadya Aisyah Nurdiyana \\ Universitas Pembangunan Nasional "Veteran" Jawa Timur \\ Marizka Distya Anastasia \\ Universitas Pembangunan Nasional "Veteran" Jawa Timur
}

\begin{abstract}
This article's background is the impact of the Coronavirus Disease 2019 (COVID-19) pandemic on the process of implementing school learning that has turned online. This article contains the process of making animated video learning media using the Powtoon application. Animated video material is the National Examination subject (Indonesian, Science, and Mathematics) for elementary school students in grades one to six. The data collection method used interviewing students, parents, teachers, village heads, PKK administrators, and youth organizations. By analyzing the problems then accomplished by making animated videos that suitable to the syllabus for each subject. The animated video is uploaded to the Sidokumpul Village Community Service Program's official Youtube channel to be accessed by all target elementary students and the wider community. Making animation is to provide learning innovation for elementary school teachers and students in Sidokumpul village and attract interest in learning. The stages of making animated videos consist of pre-production, production, and post-production. Animated videos can accelerate elementary students' understanding of the subject matter. Moreover, parental involvement in online learning provides many positive things for relationships between family members and student personality development.
\end{abstract}

Keywords: Animated Video, COVID-19, Learning Innovation, Online Learning

\section{INTRODUCTION}

Education is a topic that always interesting and current to talk about. Education is also a complex problem and will never be fully resolved. There are many complex aspects and elements to parse educational problems in order to provide satisfactory answers for various parties (Mardliyah \& Achmad, 2017). The easiest thing for Indonesian citizens to understand the word education is by referring to Law Number 20 of 2003 concerning the National Education System. Especially in article 1, paragraph 11, and article 1 paragraph 12 . Article 1 paragraph 11 states that formal education is a structured and tiered education path, which consists of basic education, secondary education and higher education. Whereas in article 1 paragraph 12 it is stated that non- 
formal education is a path of education outside of formal education which can be implemented in a structured and tiered manner.

When Indonesia has not be able to overcome the education gap, so it can be accessed by all citizens in a cheap and quality manner, the world is getting the COVID19 pandemic, a condition that forces all aspects of life to stagnate, including education. Almost all schools throughout the country are closed and eliminating face-to-face teaching and learning. All activities in teaching and learning process use online class. The prohibition of making face-to-face meetings and meeting in groups makes humans seem not to be social creatures. Meanwhile, the demands for educational institutions as a field for the growth of scientific human seeds and a place to hone the ability to think have never declined. Schools must remain a social miniature, as a place to interact with various social classes in society (Yulianingsih, Artha, \& Mardliyah, 2018). Schools must still have an important function to train their students' social skills and intelligence. Humans depend on technology, especially the internet. The internet network is the savior of human civilization during the COVID-19 pandemic. Interaction and communication can still be established, there are even more innovations in internetbased communication technology. Communication media is growing towards convergence. The forms of newspapers, radio, and television have become increasingly thin and the differences tend to overlap with each other (Achmad, 2019, 2020; Candrasari, 2020).

Since the COVID-19 hit Indonesia, the government has taken various ways to minimize its spread, one of them is through the letter of the Ministry of Education and Culture (Kemendikbud) number 4 of 2020 concerning the implementation of educational policies in the emergency period of the spread of COVID-19 by following the learning process from home through online or long distance learning. As a result, there was a sudden changed and tended to be surprising both from the teacher and student side due to a sudden change in learning culture. One of the reasons for this cultural shock is the disruption of the social adjustment system in learning, disruption of achievement motivation, and learning interactions that are not optimal (Ernofalina, 2017). Even though conducive learning activities are activities that form a pleasant atmosphere of interaction, encourage children to try, dialogue without boundaries, and students get ample opportunities to express themselves in launching their own potential (Agustin, Setiyadi, \& Puspita, 2020).

Furthermore, effective learning will equip children with pleasant and meaningful experiences that will remain in the child's mind throughout time because good learning is basically learning that provides children with challenging, creative and constructive experiences whose ultimate goal is to help children to solve the problems in the future (Daulae, 2014). This conducive learning is increasingly difficult due to the COVID-19 pandemic which causes teachers as the main teachers to experience difficulties and experience various obstacles to be able to create a conducive learning situation..

The teaching and learning process cannot be separated from the strategies, methods and media used by the teacher (Panjaitan, Yetti, \& Nurani, 2020). Positive learning is the realization of teacher action to show professionalism based on the experiences and practices they do and have, if this is constrained it will be difficult to obtain an increase in the quality of learning especially if the elements of pedagogic interaction in learning also fade (Gore et al., 2017 ). In this case, effective learning will be difficult to achieve among elementary school students because elementary school students still need to be guided and supervised when studying or doing assignments in 
order to achieve the competency standards that have been made by the school or the Ministry of Education. It cannot be denied that the teacher's role in learning holds a very important, strategic position and is even the key to achieving quality and effective learning (Ronkainen, Kuusisto, \& Tirri, 2019).

Related to child-centered teaching behavior, it is conveying learning with educational interactions between teachers and students so as to create a democratic atmosphere. In addition, there are varied teaching methods, teachers have professional skills, the teaching materials are suitable for children's development, and a safe and comfortable environment. To attract active student involvement, means that support learning effectiveness are needed (Yusuf, 2017). To realize effective learning, the teacher as the main character in learning is required to be an effective teacher as well, namely teachers who use the maximum teaching time, presenting material with various methods, monitoring programs and progress through student assessment, designing learning opportunities for students. to apply learning experiences, willing to repeat the material when the child does not understand it, set learning targets for each child (Setyosari, 2017).

One of the alternative forms of learning that can be implemented during the emergency period of COVID-19 is the online learning system. Online learning is learning that uses internet networks with accessibility, connectivity, flexibility, and the ability to generate various types of learning interactions (Moore, Dickson-Deane, \& Galyen, 2011). Several studies have shown that the use of the internet and multimedia technology is able to change the way of conveying knowledge and can be an alternative learning media to promote tradition, morality, and religion (Achmad, 2019, 2020).

In practice, online learning requires the support of mobile devices such as smartphones, tablets and laptops which can be used to access information anywhere and anytime (Gikas \& Grant, 2013). The use of technological mobility has a major contribution in achieving distance learning goals. Various media can also be used to support the implementation of online learning. For example, virtual classes use Google Classroom, Edmodo, and Schoology services. Online learning can even be done through social media such as Facebook and Instagram (Mushlihah, Yetri, \& Yuberti, 2018; Nurkamid, Dahlan, Susanto, \& Khotimah, 2010; Rubiyati, Muhamad Asrori, 2017).

At this time, Smartphones or Androids are the main media in the teaching and learning process. Couple with the online learning policy imposed by the Gresik Regency Government as an effort to break the chain of transmission of COVID-19. On the other hand, online learning often makes children bored and bored, so that students cannot properly absorb the material presented by the teacher. Besides that, they also cannot interact and play with their friends so they are easily stressed. So it is not surprising that in this condition many children are reluctant to learn and prefer to play. Therefore, online learning innovations need to be carried out by all teaching staff so that students do not feel bored in the learning process. Optimizing the use of technology in learning by using animated videos is one of the community service activities carried out to overcome educational problems due to COVID-19.

For this reason, one form of social activity carried out by students of the Universita Pembangunan Nasional "Veteran" in East Java is to dedicate the knowledge which they have mastered to people affected by COVID-19 in the field of education. The online learning process complained of by parents, teachers and elementary school students is the main target that gets the attention of this group of students. As a combination of various scientific fields (Science and Social Humanities), working 
together to make animated videos as an innovative learning media for the subject of national exam (Indonesian, Science, and Mathematics). The target area of this group is Sidokumpul Village for the KKN Regular for COVID-19. A new concept in the implementation of KKN program is implemented as a form of implementation of Government Regulations by limiting the movement of mass activities in the community. So many KKN programs in 2020 will be carried out with online-based programs.

The challenges that must be faced by Field Assistance Lecturers with their guidance students are mapping the problems and needs of people affected by COVID19. The online learning innovation division in charge of Sidokumpul Village decided to design and decide on a program that would have an innovative impact not only on elementary school students and teachers in Sidokumpul Village but also throughout Indonesia. Because, the output of the animation video produced by the online learning innovation division appear on Youtube and is useful for the wider community.

\section{RESEARCH METHODS}

Before create a planning activities, all members of the online learning innovation division collected data by conducting interviews with village officials, PKK administrators, youth organizations, teachers, and children of primary school age. The information collected is about the various difficulties faced in carrying out the teaching and learning process, especially for the implementation of a new curriculum that adapts to the COVID-19 pandemic. The practice of having to learn from each other's homes using the online method is not as easy as planned in the government program.

This team also explored data regarding online learning practices that have been carried out by teachers who teach at Sidokumpul Elementary School. In addition, the team identified the support of parents, RT / RW administrators and village officials for the online learning process so that children can study actively in pandemic conditions.

After collecting all the problems, the team identifies the qualifications of the team personnel. What abilities does each member have. So the team decided to produce animated instructional videos. The conditions that support are, (1) the area of Sidokumpul Urban Village is in a very good $3 \mathrm{G}$ and $4 \mathrm{G}$ signal network area from all GSM providers. (2) RT and RW have prepared a hotspot for free wi-fi access for all elementary school age children to study. The hotspot center point is located at the Posko Kampung Tangguh Semeru, to make it easier for residents with economic difficulties to use wifi facilities when needed.

The method of communication between members of the online learning innovation division and all elementary school children in the Sidokumpul family uses the WhatsApp application. In addition to communicating offline learning schedules and lesson consultation, the group is also used to share the website address where the animated video will be studied. The finished videos are uploaded to the official YouTube account of KKN 45 Sidokumpul to make it easier for elementary school children in the Sidokumpul Village and the wider community to view and learn material for the Primary School National Examination.

\section{RESULT AND DISCUSSION}

Some of the problems found include: (1) not all children have cellphones to communicate or do online learning so they use their parents' cellphones to attend online classes organized by the school. (2) not all teachers have the capability to create online learning media. (3) the amount of free time the children have, after class hours, so that 
they are more used to play with friends who live close to each other. Playing together has the potential to gather large numbers of children and this raises concerns for parents. While parents are still working, supervision of children when playing is very weak.

The identification of these problems becomes the basis for the online learning innovation division team to carry out a combination of learning programs between offline and online. For offline learning, all primary school-aged children in the Sidokumpul family are divided into class groups (1-3) and classes (4-6). The goal is to make it easier for the team to provide material and for children to also more easily adapt material from the online learning innovation division and subject matter themes provided by the school. As a means of communication for the online learning innovation division team with children, is to use the WhatApp group to communicate additional lesson schedules in several agreed locations, including the Village Hall, the Kampung Tangguh Post, the People's House, or the Al-Quran Reading Park in the mosque.

As for online learning, the concept chosen was the creation of an interesting animated video so that children could see the visualization of the subject matter. The video material is designed according to the level of understanding of each grade level in Elementary Schools. At certain agreed hours, children at certain grade levels are directed to watch and study videos on Youtube, for 15 minutes. While watching the video, children must be accompanied by their parents. After watching the video, there were quizzes that were relevant to the video material, which the children had to answer through the WhatsApp group.

For a month (1 to 28 July 2020) the entire online learning process takes place. And at the end of the last 3 days of service, the members of the division went to three meeting points with the target elementary students. The goal is to do quizzes to assess the level of children's understanding of the subject matter that has been studied for one month. For children who managed to answer correctly, gifts were given in the form of packages of healthy food and drinks. Together with the Field Advisory Lecturers, the team of the online learning innovation division provided learning motivation to elementary school children and presented all the videos and provided counseling on making animated videos for elementary school teachers in Sidokumpul. The goal is that teachers, parents, children still have the enthusiasm to carry out the teaching and learning process in the midst of a pandemic.

\section{The Process of Creating Animation Video}

\section{Pre Production Stage}

The team conducted field observations in Sidokumpul Village, Gresik District, Gresik Regency to map problems related to the needs that needed by the community. One of them is overcoming children's boredom following the online teaching and learning process. Then, planning a learning program aimed at elementary school aged children from grade 1 to grade 6 in Sidokumpul Village.

The next step is to discuss with elementary school teachers to design a syllabus to fit the semester learning plan for each subject. This is to make it easier for the team to make videos that match the topics discussed in each subject. Also to facilitate the design of animation visualization so that elementary students can more easily understand the material. 
2. Production Stage

After the syllabus has been completed, proceed with the steps for creating an animated video. Animation is a series of images that form a movement. One of the advantages of animation over other media such as static images or text is its ability to describe changing circumstances over time. This is especially helpful in explaining the procedure and sequence of events (Dina, 2011). With the animation software such as Adobe Flash, Adobe Director, Swift 3D, 3D Studio MX, and several others. Or through web animation makers such as Powtoon, Animaker, and Filmora, which provide easy animation as a learning tool. So at this time, it no longer requires special skills and high costs. However, creating animations still requires a lot of time, and the most important thing is additional skills, namely art and creativity.

This stage really requires the members of the online learning innovation division to devote all their creativity and audiovisual design skills. Based on the results of interviews with elementary students in Sidokumpul Village, almost all of them prefer audio-visual media as a combination of sound and visual elements. Audiovisual media are considered more attractive to elementary students when used in the learning process.

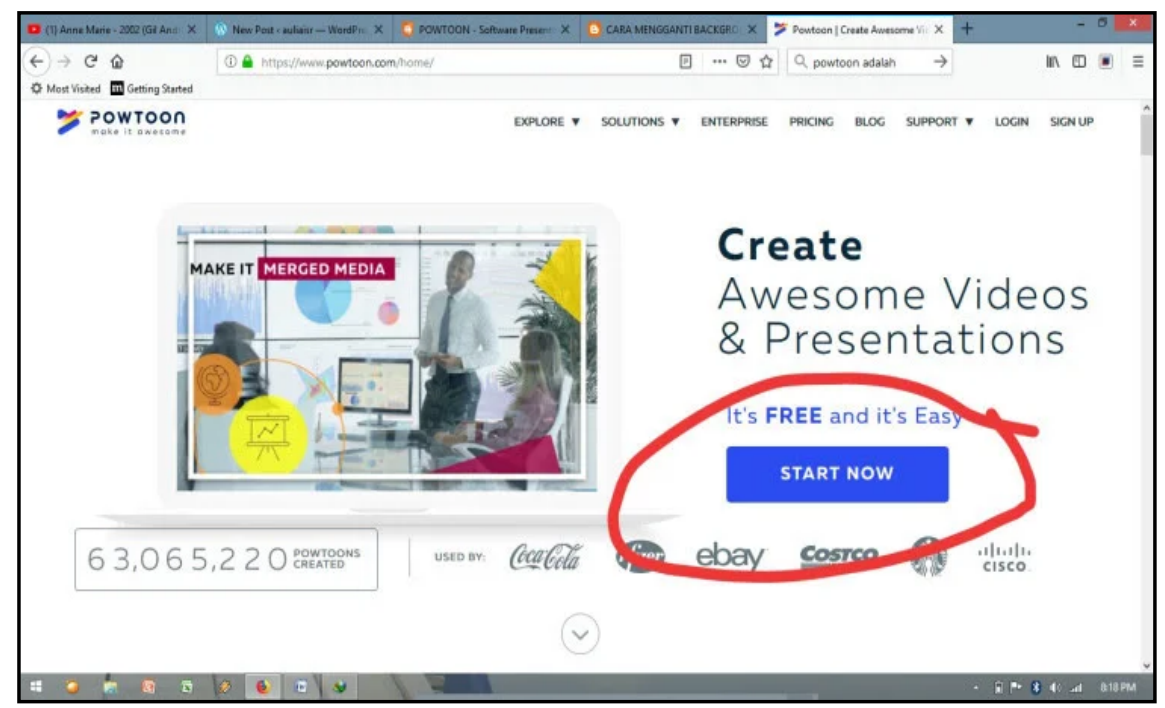

Figure 1: Powtoon initial view

Creating animated videos is using the Powtoon application as a tool that can produce quality videos. The following is how to make a video via Powtoon:

1. Open the laptop or Personal Computer (PC) then turn it on by making sure the laptop or PC is connected to a strong internet connection.

2. Open an internet window on your laptop or PC, you can use Mozilla Firefox, Google Chrome or others.

3. Search Powtoon in the search field.

4. Then on the computer screen the Powtoon application start page will appear, then click Start Now (Figure 1). That's when the Powtoon application can run.

5. After that, the account creation request page appears (figure 2). Users are asked to enter their e-mail and e-mail password to create a Powtoon account. Or log in using a google account. facebook, office, or linkedin. 


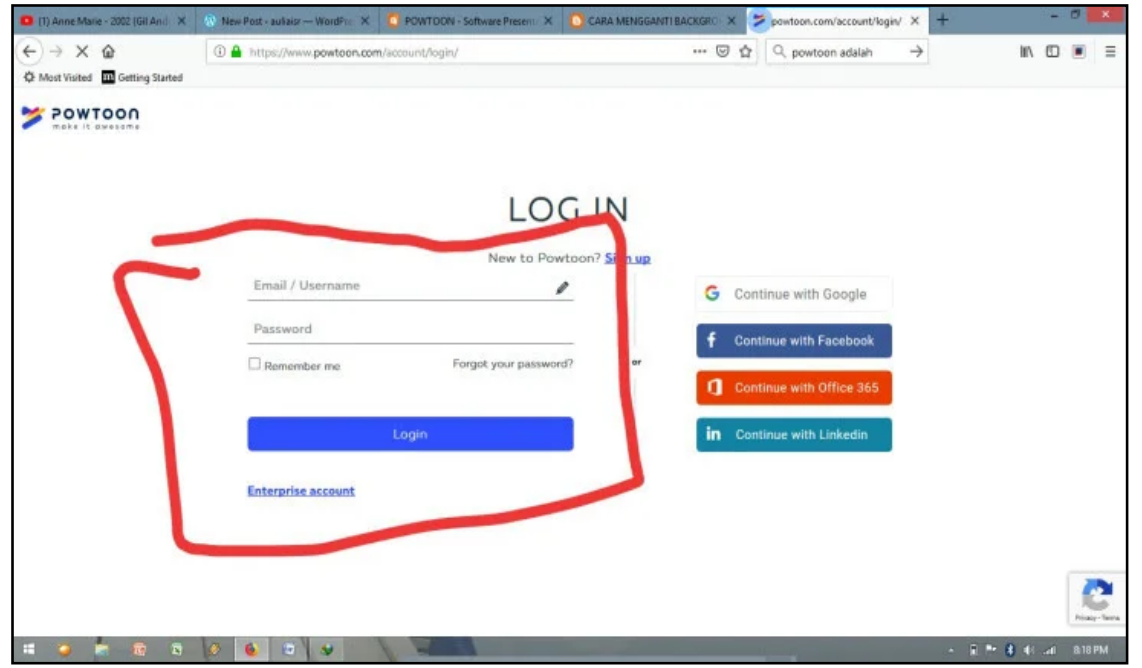

Figure 2: Display login on Powtoon

6. After successfully entering the Powtoon application, the user's computer screen will display a wide selection of templates and themes. Users can use templates or themes that have been provided or can create their own templates. If you don't want an available theme, the user can close the page by clicking the cross $(\mathrm{X})$ in the upper right corner of the screen.

7. At the bottom of the screen there is a blue box that says Blank Powtoon. The user can click on the blue box to create a template according to the user's wishes (figure 3). After clicking the box that says Blank Powtoon, the screen will change to editing readiness.

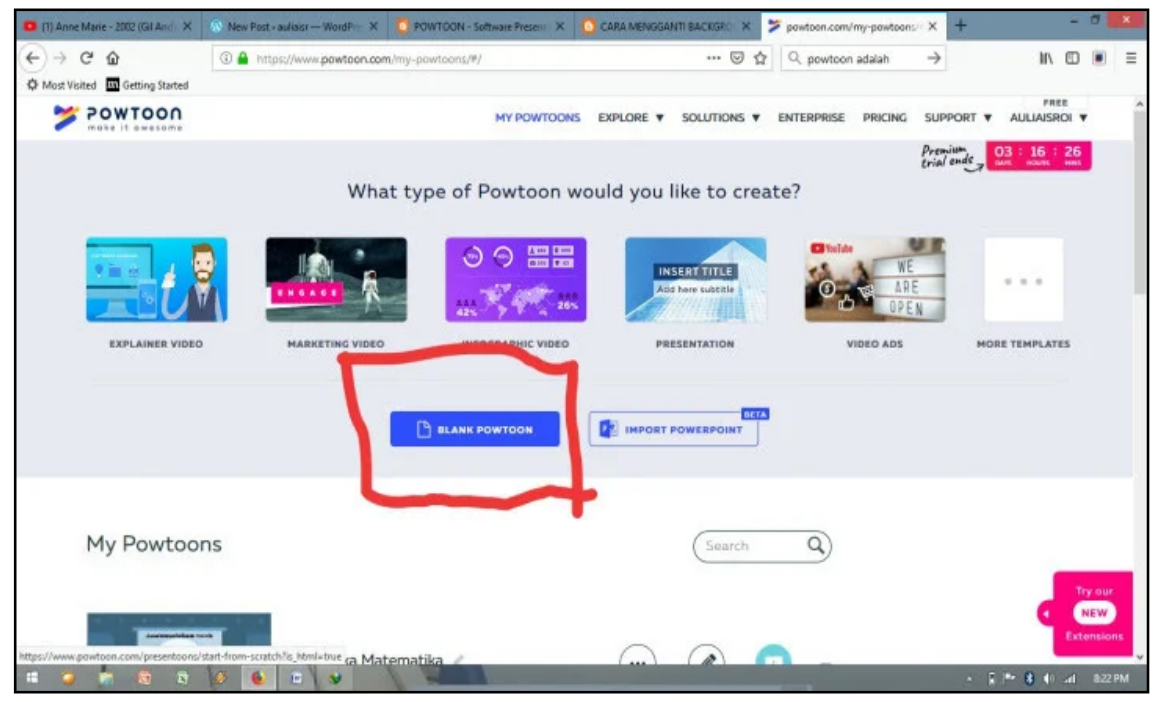

Figure 3: The view of entering the project by clicking "blank powtoon"

8. After the Blank Powtoon page appears (figure 4), you can create videos according to your wishes. Powtoon's features are located on the right side, with these features you can create videos according to each person's taste and creativity. 


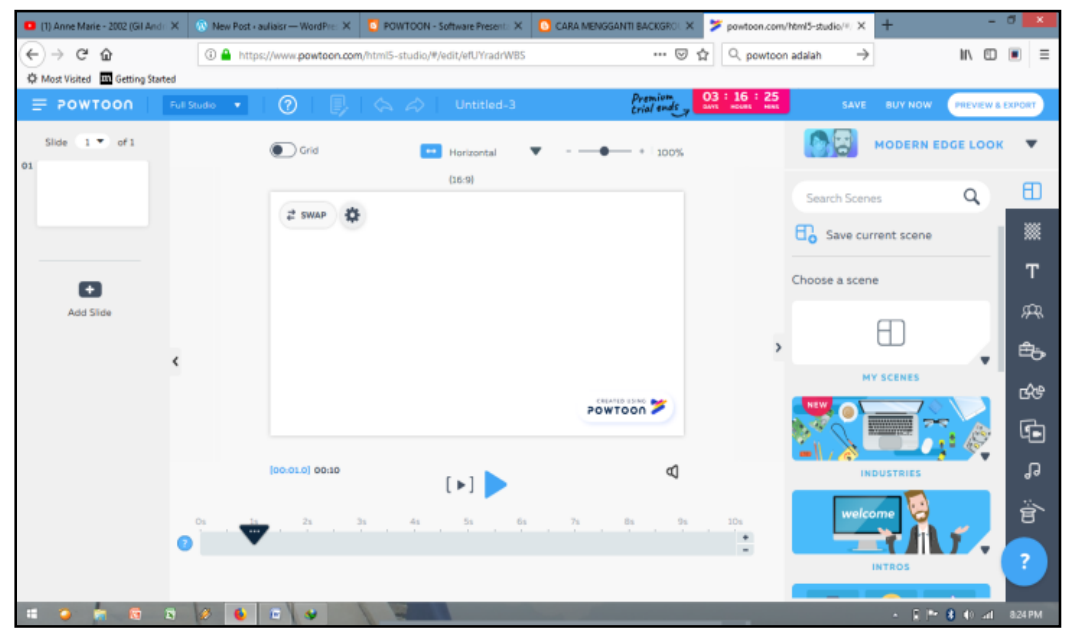

Figure 4: Display editing page on Blank Powtoon

The feature options are listed in black columns, with various symbols. Each feature symbol is equipped with a description of the feature's use, if the arrow (cursor) is directed at the symbols. For example, in symbol number 2 (two) from above, there is a background feature and description, then when you click on that feature, various backgrounds will appear for the slide which will later become a video.

9. To add a slide, simply click on the "Add Slide" section located on the left (figure 5). Aim to increase the number of slides as needed.

10. If you are going to adjust the video time, click the plus sign $(+)$ to increase the time duration and click the minus sign (-) to reduce the time. This sign is at the bottom right of the video editing screen.

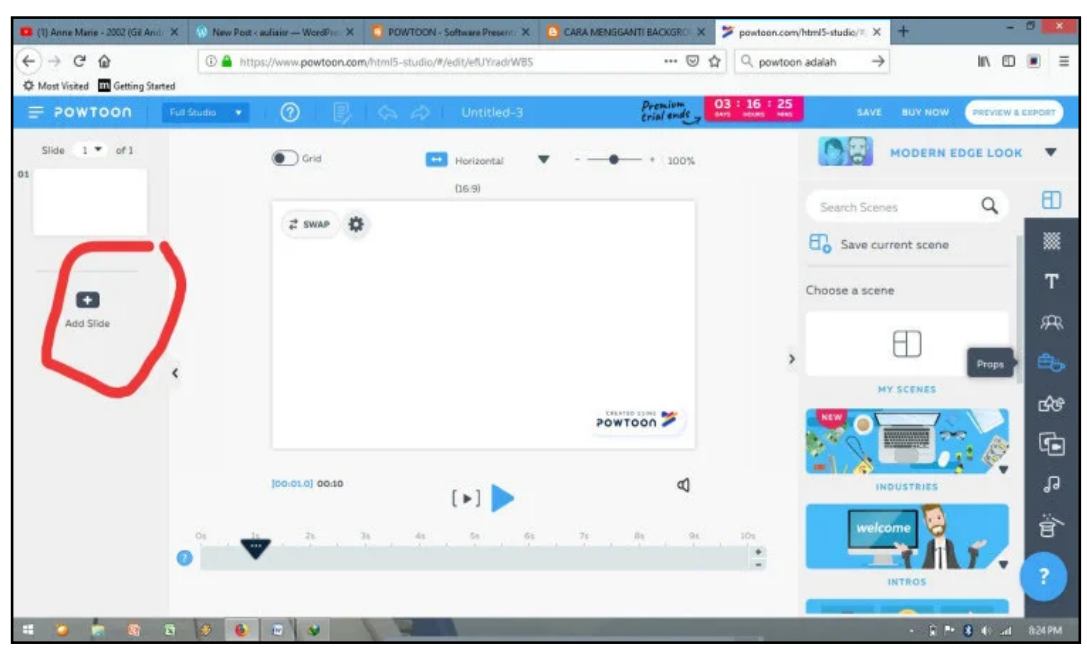

Figure 5: The add slide show on Powtoon

11. When finished making the video, click "save" which is on the top right, next to the words Buy Now (picture 6). After clicking save, the Powtoon animation will be saved automatically. 


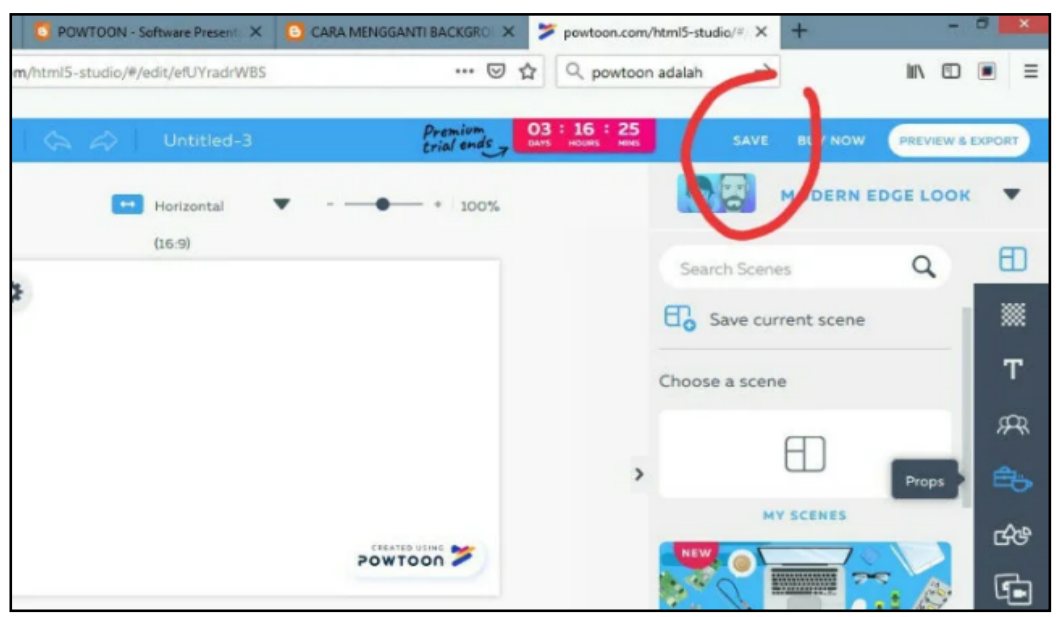

Figure 6: Display save on Powtoon

12. Thus the editing of the video results has been stored in the user account. If you want to upload a video that has been created, the user needs to return to the home page. You do this by clicking the arrow to the left $(\leftarrow)$ located at the top left of the screen display.

13. On the front page of the Powtoon application, there are several animated video results that have been made. Scroll down the screen or click My Powtoon to see all the animation results. It only remains to choose a certain animation to be renamed first, before uploading it to another application or website.

14. To change the name of the video, find the pencil drawing and click it. Type the name of the video as desired by the user

15. If the user will upload the animation he made, click the "export" icon to the right of the pencil drawing (figure 7).

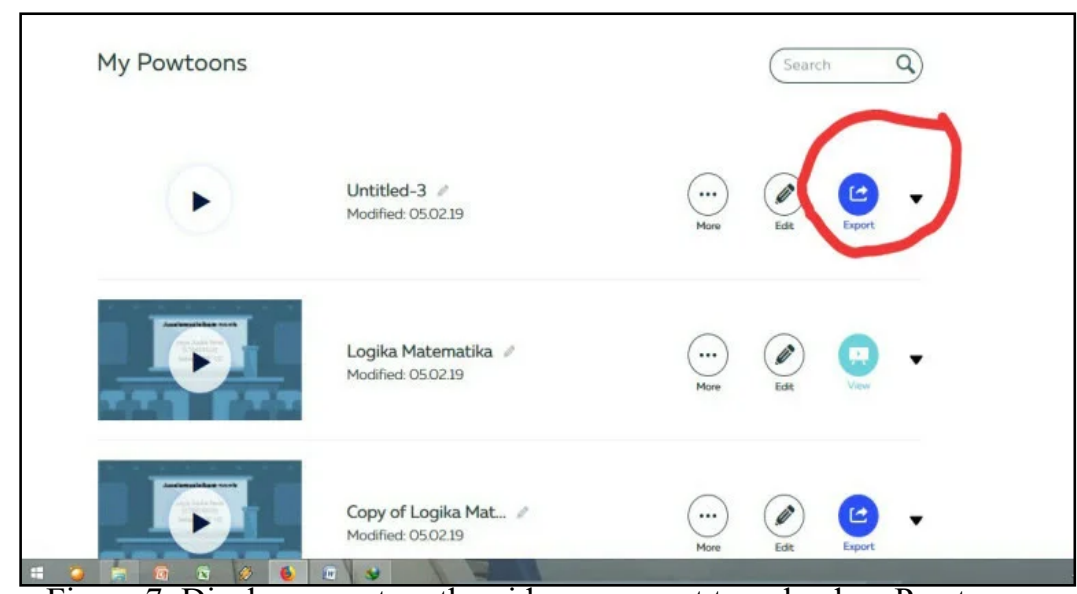

Figure 7: Display export on the video you want to upload on Powtoon

16. After the user clicks export, a selection of applications and websites will appear for the purpose of uploading the animated video that has been made. The user can select one, then click and you're done. For this online learning innovation division project, the website for uploading in Youtube. 


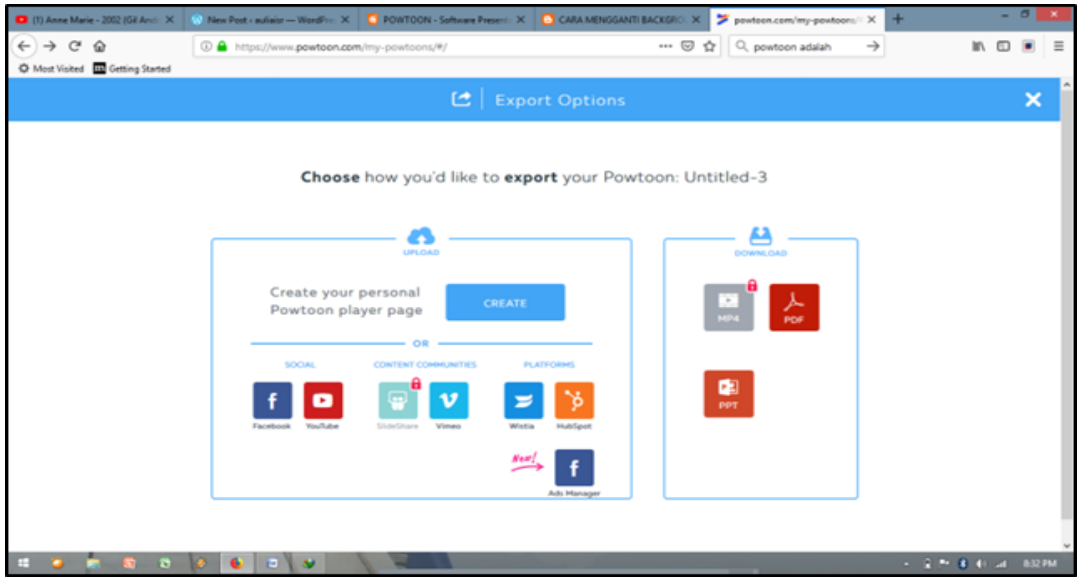

Figure 8. Display export on Powtoon

\section{Post Production Stage (Implementation of results)}

After all the results of the animated video are uploaded on Youtube KKN Sidokumpul (KKN 45 Sidokumpul, 2020), All team members and DPL provide explanations to all elementary school students and parents through the WhatsApp group, about the lesson plans and materials that are in accordance with the school syllabus structure. WhatApp numbers are used by children, mostly shared with their parents.

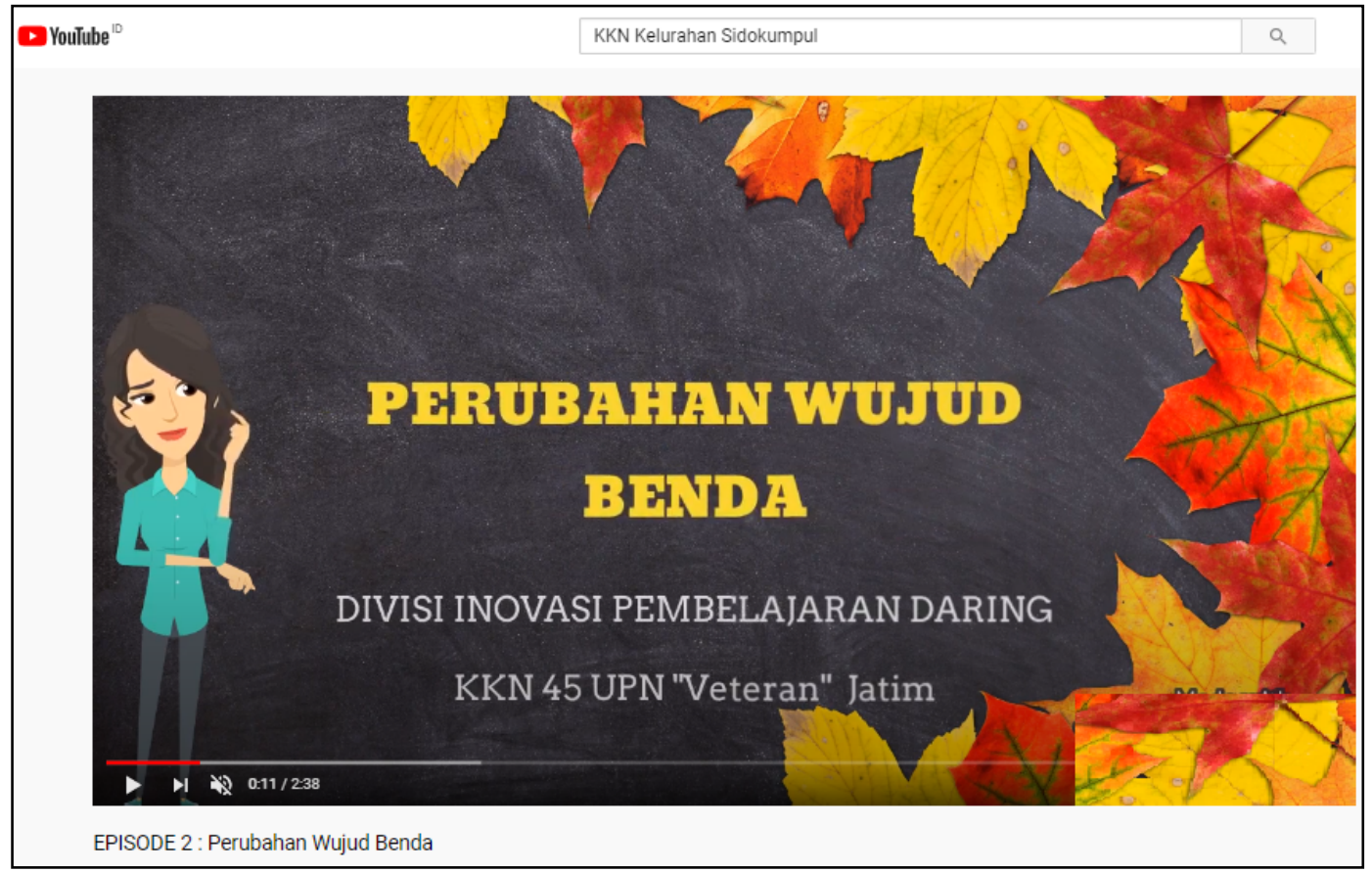

Figure 9: An animated video of a Science subject (https://www.youtube.com/watch?v=1eh1mZ1NtdU)

The online learning innovation division team provides a Youtube link address containing animated videos, so that students and parents can access certain videos according to the learning material. During the online learning session through WA, students are allowed to be accompanied by their parents to interact during the question and answer session. The goal is to establish communication between parents and children about learning materials and so that students can more easily understand the 
material provided. After the video learning time (15 minutes) and the online learning time (20-30 minutes) were over, the online learning innovation division team shared a google form containing questions about animated videos. The time allotted for answering these questions is 15 minutes. The results of the question and answer session in WA and answers from the google form will be accumulated to get data on the most active participants and the best companion parents to be given prizes as a stimulus so that students are more active in studying.

The learning outcomes for one month are then evaluated jointly by the team of the online learning innovation division, field supervisors, and school teachers. There are many positive things that deserve attention so that the online learning program with animated videos of national exam subjects, among others: (1) the students are very enthusiastic about studying the material in the form of audio-visual media. (2) it becomes easier for students to understand the material according to the course syllabus and not get bored because they have to continue learning by reading books. (3) teachers need special training in making animated videos as a learning innovation. (4) the involvement of parents in online learning brings closer communication with their children. In the conditions of the COVID-19 pandemic, parents have a very vital role in the success of student learning because they become a substitute for teachers when studying at home (Mardliyah, Yulianingsih, \& Putri, 2020). Parents are grateful for being able to participate in learning activities while at the same time supervising the use of devices by their children, so that children are protected from bullying, pornography, the spread of had, and wise social media (Achmad, Wiranata, \& Mardliyah, 2016; Alamiyah, 2020; Claretta) , Candrasari, \& Arianto, 2018; Tutiasri, Kusuma, \& Sumardjijati, 2019).

Village officials, RT / RW, PKK administrators, and youth organizations support the smooth running of online learning through animated videos by providing hotspot networks, gifts (healthy food and basic food packages) for children and parents who work well together during program implementation. Giving prizes as a reward for learning activities for children and parents is the motivation for learning competitions. In the concept of education, gifts or awards are one of the tools to increase the motivation of students. This method can associate rewards for a person's good deeds and behavior, and usually feeling happy will lead the person to repeat good deeds. Respect is an element of discipline that is very important in self-development and children's behavior. A person will continue to strive to improve and maintain discipline if the implementation of that discipline results in achievement and productivity which are then rewarded. In this case, the teacher or the school can work together with the parents of students in providing prizes for students who have been active and enthusiastic in participating in distance learning and managed to get good grades in class (Kompri: 2016).

\section{CONCLUSION}

Learning innovations during the COVID-19 pandemic, for national exam subjects (Indonesian, Science, and Mathematics) for elementary school students, became easier to understand by using animated video learning media. The making of animated videos must be adjusted to the syllabus and material that has been prepared in the learning plan. Audio-visual media has an appeal for elementary school age children and facilitates students' understanding of the subject matter. 
The practice of learning innovation through animated videos is widely available on the internet and easy to learn. One of them is Powtoon, which doesn't take too long for teachers to master creating animation video.

Online learning by providing many animated videos on Youtube with the participation of parents, provides various positive things, for relationships between family members and the development of children's personalities. As well as protecting children from various bad influences on the use of gadgets and accessing harmful content from the internet.

\section{REFERENCES}

Achmad, Z. A. (2019). Integrasi Program Dakwah dan Budaya: Studi Etnografi Virtual Mediamorfosis Radio Nada FM Sumenep Madura. Jurnal Komunikasi Islam, 09(2), 238-263. https://doi.org/10.15642/jki.2019.9.2.239-263

Achmad, Z. A. (2020). Review Buku: Mediamorphosis: Understanding New Media by Roger Fidler. In E. R. Nawangsari \& A. Kriswibowo (Eds.), Potret Masyarakat dan Kebijakan Pemerintah dalam menghadapi tantangan Pandemi Covid-19 (pp. 71-78). Retrieved from http://adneg.upnjatim.ac.id/index.php/component/k2/item /119-potret-masyarakat-dan-kebijakan-pemerintah-dalam-menghadapi-tantanganpandemi-covid-19

Achmad, Z. A., Wiranata, I. M. A., \& Mardliyah, S. (2016). Teenagers are Subjected to Cyber Bullying in Social Media Ask.fm. Re-Examining Governance: Strengthening Citizenship In The Changing World, ICOCSPA 2016, 435-441. https://doi.org/978-602-18461-4-8

Agustin, M., Setiyadi, R., \& Puspita, R. D. (2020). Burnout Profile Of Elementary School Teacher Education Students (Estes): Factors And Implication Of Guidance And Counseling Services. PrimaryEdu - Journal of Primary Education, 4(1), 38. https://doi.org/10.22460/pej.v4i1.1640

Alamiyah, S. S. (2020). 'I Become More Confident': Mother Use of Online Platform for Parenting Information. 423, 511-523. https://doi.org/10.2991/assehr.k.200325.039

Candrasari, Y. (2020). Mediated Interpersonal Communication: A New Way of Social Interaction in the Digital Age. Proceedings of the 2nd International Media Conference 2019 (IMC 2019). https://doi.org/10.2991/assehr.k.200325.041

Claretta, D., Candrasari, Y., \& Arianto, I. D. (2018). Mother's Strategy on Child Mentoring in Using the Internet. (October), 357-363. https://doi.org/10.11594/nstp.2018.0152

Daulae, T. H. (2014). Menciptakan Pembelajaran yang Efektif. Forum Pedagogik, 06(02), 134.

Ernofalina, E. (2017). Culture Shocks Experienced by Indonesian Students Studying Overseas. International Journal of Educational Best Practices, 1(2), 87. https://doi.org/10.31258/ijebp.v1n2.p87-105

Gikas, J., \& Grant, M. M. (2013). Mobile computing devices in higher education: Student perspectives on learning with cellphones, smartphones \&amp; social media. The Internet and Higher Education, 19, 18-26. https://doi.org/10.1016/j.iheduc.2013.06.002 
Gore, J., Lloyd, A., Smith, M., Bowe, J., Ellis, H., \& Lubans, D. (2017). Effects of professional development on the quality of teaching: Results from a randomised controlled trial of Quality Teaching Rounds. Teaching and Teacher Education, 68, 99-113. https://doi.org/10.1016/j.tate.2017.08.007

KKN 45 Sidokumpul. (2020). Perubahan Wujud Benda. Retrieved 26 July 2020, from YouTube website: https://www.youtube.com/watch?v=1eh1mZ1NtdU

Mardliyah, S., \& Achmad, Z. A. (2017). Binary Opposition in the Educational Study in Indonesia: Non Formal Education Deconstructs Formal Education. International Conference on Education Innovation (ICEI), 772-777. Surabaya: Faculty of Education, Universitas Negeri Surabaya.

Mardliyah, S., Yulianingsih, W., \& Putri, L. S. R. (2020). Sekolah Keluarga: Menciptakan Lingkungan Sosial untuk Membangun Empati dan Kreativitas Anak Usia Dini. Jurnal Obsesi: Jurnal Pendidikan Anak Usia Dini, 5(1), 576. https://doi.org/10.31004/obsesi.v5i1.665

Moore, J. L., Dickson-Deane, C., \& Galyen, K. (2011). e-Learning, online learning, and distance learning environments: Are they the same? The Internet and Higher Education, 14(2), 129-135. https://doi.org/10.1016/j.iheduc.2010.10.001

Mushlihah, K., Yetri, Y., \& Yuberti, Y. (2018). Pengembangan Media Pembelajaran Berbasis Multi Representasi Bermuatan Sains Keislaman dengan Output Instagram pada Materi Hukum Newton. Indonesian Journal of Science and Mathematics Education, 1(3), 207-215. https://doi.org/10.24042/ijsme.v1i3.3595

Nurkamid, M., Dahlan, M., Susanto, A., \& Khotimah, T. (2010). Pemanfaatan aplikasi jejaring sosial facebook untuk media pembelajaran. Jurnal Sains Dan Teknologi, $3(2), 1-16$.

Panjaitan, N. Q., Yetti, E., \& Nurani, Y. (2020). Pengaruh Media Pembelajaran Digital Animasi dan Kepercayaan Diri terhadap Hasil Belajar Pendidikan Agama Islam Anak. Jurnal Obsesi: Jurnal Pendidikan Anak Usia Dini, 4(2), 588. https://doi.org/10.31004/obsesi.v4i2.404

Ronkainen, R., Kuusisto, E., \& Tirri, K. (2019). Growth Mindset in Teaching: A Case Study of a Finnish Elementary School Teacher. International Journal of Learning, Teaching and Educational Research, 18(8), 141-154. https://doi.org/10.26803/ijlter.18.8.9

Rubiyati, Muhamad Asrori, L. W. (2017). Pengaruh Pemanfaatan Media Sosial Instagram Terhadap Kreativitas Belajar Pada Remaja Kelas VII. Jurnal Untan, 18. Retrieved from http://jurnal.untan.ac.id/index.php/jpdpb/article/download/25681 $\underline{175676576765}$

Setyosari, P. (2017). Menciptakan Pembelajaran Yang Efektif Dan Berkualitas. JINOTEP (Jurnal Inovasi Dan Teknologi Pembelajaran) Kajian Dan Riset Dalam Teknologi Pembelajaran, 1(5), 20-30. https://doi.org/10.17977/um031v1i12014p020

Tutiasri, R. P., Kusuma, A., \& Sumardjijati, S. (2019). Perilaku Remaja dalam Penyebaran Hoax di Grup WhatsApp. Jurnal Ilmu Komunikasi, 2(1). https://doi.org/10.33005/jkom.v2i1.36 
Yulianingsih, W., Artha, I. K., \& Mardliyah, S. (2018). Lifelong Learning as a Response toward Learning Society. Proceedings of the 1st International Conference on Education Innovation (ICEI 2017). https://doi.org/10.2991/icei17.2018.99

Yusuf, B. B. (2017). Konsep Dan Indikator Pembelajaran Efektif. Jurnal Kajian Pembelajaran Dan Keilmuan, 1(1), 13-20. Retrieved from http://jurnal.untan.ac.id/index.php/jurnalkpk/article/view/25082/75676576424 